\title{
Dynamics change of chemical compounds in the composition of the dust aerosol on period of dust storms in Tajikistan
}

\author{
Mukhammad I. Khodzhakhon*, Bahron I. Nazarov, Sabur F. Abdullaev, and Rafika A. Karieva \\ S.U. Umarov Physical-Technical Institute, Academy of Sciences of the Republic of Tajikistan, Dushanbe, Tajikistan
}

\begin{abstract}
This contribution presents the composition of dust aerosol collected in dust storms in the territory of the weather station Ayvaj southern Tajikistan, during the years 2007-2015. High concentrations of the compounds $\mathrm{SiO}_{2}$ (54.23\%), $\mathrm{CaO}$ (11.25\%) and $\mathrm{Al}_{2} \mathrm{O}_{3}$ (10.16\%) were found, which is characteristic for dust. The statistical characteristics of measured compounds is determined and the correlation coefficients between certain compounds are calculated. A significant high correlation is observed between $\mathrm{SiO}_{2}$ and $\mathrm{Na}_{2} \mathrm{O}(\mathrm{r}=0.98)$, between $\mathrm{Fe}_{2} \mathrm{O}_{3}$ and $\mathrm{SO}_{3}(\mathrm{r}=0.89)$, between $\mathrm{Fe}_{2} \mathrm{O}_{3}$ and $\mathrm{Al}_{2} \mathrm{O}_{3}$ as well as between $\mathrm{K}_{2} \mathrm{O}$ and $\mathrm{MgO}(\mathrm{r}=0.89)$.
\end{abstract}

\section{Introduction}

Mineral dust plays an important role in the optical, physical and chemical processes in the atmosphere, while dust deposition adds exogenous mineral and organic material to terrestrial surfaces, having a significant impact on the Earth's ecosystems and biogeochemical cycle [1-10].

To study the content of chemical compounds in the dust aerosol during dust storms, an x-ray fluorescence wave dispersion spectrometer S8 TIGER by Bruker was used. In the spectrometer, the samples are irradiated by an $\mathrm{x}$-ray tube with energies up to $60 \mathrm{keV}$. Typically, samples are measured in vacuum, which can significantly reduce the detection limits, especially for light elements. In the case of liquid samples or unbound powders, measurements are carried out in a nitrogen or helium atmosphere. $\mathrm{X}$-ray radiation is generated by the tube and hits the sample, which in turn emits x-rays of a certain wavelength, which is the characteristic radiation that uniquely determines the element of the periodic system. To generate this radiation, the energy of the primary (exciting) beam must be greater than the excitation energy of the characteristic radiation.

\section{Sample preparation}

The most commonly used sample preparation for x-ray fluorescence analysis is tablet compression. This is a fairly simple and fast method: select and measure the right amount of sample on the scales, grind and compress into a tablet. To accurately reproduce the results, it is important to choose a method only once and then use it constantly. To obtain more accurate results on the main trace elements, it is necessary to mix the sample with flux and melt in an oven. After cooling, you will get a homogeneous glass disc. Thus, the process of sample preparation for $\mathrm{x}$-ray fluorescence analysis is quite simple, fast, does not require special training and skills, and therefore can be fully automated.

Sample preparation (Tab. 1) for S8 TIGER for fused discs (Geo-Quant) includes the following steps:

1. Determination of the mass loss (LOI - loss on ignition)

1.1. A sample (about $3 \mathrm{~g}$ ) is placed in a muffle furnace at a temperature of $\mathrm{T}=1100^{\circ} \mathrm{C}$, and for 1 hour.

1.2. We calculate the LOI using the formula: LOI $=(\mathrm{m} 1-\mathrm{m} 2) / \mathrm{m} 1$, where $\mathrm{m} 1$ is the mass of the material before heating and $\mathrm{m} 2$ after heating.

2. In $0.63 \mathrm{~g}$ of the sample, a flux is added. In our case, the flux consists of $3.14 \mathrm{~g}$ of lithium tetraborate $\left(\mathrm{Li}_{2} \mathrm{~B}_{4} \mathrm{O}_{7}\right)$ and $3.14 \mathrm{~g}$ of lithium metaborate $\left(\mathrm{LiBO}_{2}\right)$.

3. Add $0.16 \mathrm{ml}$ of $\mathrm{LiBr}$ solution to the sample to increase wetting. A solution is preliminarily prepared: $25 \mathrm{ml}$ of water $+5 \mathrm{~g}$ of $\mathrm{LiBr}$.

4. After mixing, the sample is placed in a melting pot (katanax), where the sample first melts at $1150^{\circ} \mathrm{C}$ for 15 minutes and then cools. The GEO-QUANT program analyzes the resulting disc for 6-7 minutes.

\section{Results}

The average values of the content of chemical compounds in the dust aerosol for the period 2007-2015 is shown in Fig. 1

\footnotetext{
* Corresponding author: kh.mukhammad.i@gmail.com
} 
The following chemical compounds define the composition of the dust aerosol: $\mathrm{SiO}_{2}(54.23 \%)$, $\mathrm{CaO}(11.25 \%), \quad \mathrm{Al}_{2} \mathrm{O}_{3}(10.16 \%), \quad \mathrm{Fe}_{2} \mathrm{O}_{3}(3.67 \%)$, $\mathrm{MgO}(2.21 \%), \mathrm{K}_{2} \mathrm{O}(1.91 \%)$ and $\mathrm{Na}_{2} \mathrm{O}(1.75 \%)$. The content of other compounds measured is less than $1 \%$ (Fig 1). The frequency of occurrence of the composition of the individual particles of dust aerosol elements is arranged in the following sequence: $\mathrm{Si}$, $\mathrm{Al}, \mathrm{Ca}, \mathrm{K}, \mathrm{Fe} . .$. , which agrees well with the data of integral determination of the elemental composition of the aerosol [1-4].

Table 1: Preparation of sample components

\begin{tabular}{|c|c|c|c|c|c|c|c|}
\hline \multirow[b]{3}{*}{ Years } & \multirow{2}{*}{\multicolumn{7}{|c|}{ components }} \\
\hline & & & & & & & \\
\hline & $\mathrm{m}_{\text {erucible }}$ & $\mathrm{M}_{\text {maetrial }}$ & $\begin{array}{l}\mathrm{M}_{\text {crucible }} \\
\mathrm{m}_{\text {material }}\end{array}$ & $\mathrm{M}_{\text {total }}$ & LOI, $\%$ & $\mathrm{LiBO}_{2}$ & $\mathrm{Li}_{2} \mathrm{~B}_{4} \mathrm{O}_{7}$ \\
\hline 2007 & 19.5 & 8.19 & 27.69 & 26.34 & 16.48 & 3.17 & 3.17 \\
\hline 2008 & 19.6 & 10.5 & 30.1 & 28.84 & 12 & 3.17 & 3.17 \\
\hline 2009 & 16.8 & 8.64 & 25.44 & 24.53 & 10.53 & 3.17 & 3.17 \\
\hline 2010 & 19.14 & 7.31 & 26.45 & 25.6 & 11.63 & 3.17 & 3.17 \\
\hline 2011 & 19.12 & 1.65 & 20.77 & 20.41 & 21.82 & 3.17 & 3.17 \\
\hline 2013 & 17.63 & 10.65 & 28.28 & 26.98 & 12.21 & 3.17 & 3.17 \\
\hline 2014 & 19.88 & 8.35 & 28.23 & 27.25 & 11.74 & 3.17 & 3.17 \\
\hline 2015 & 18.67 & 11.4 & 30.07 & 28.54 & 13.42 & 3.17 & 3.17 \\
\hline
\end{tabular}

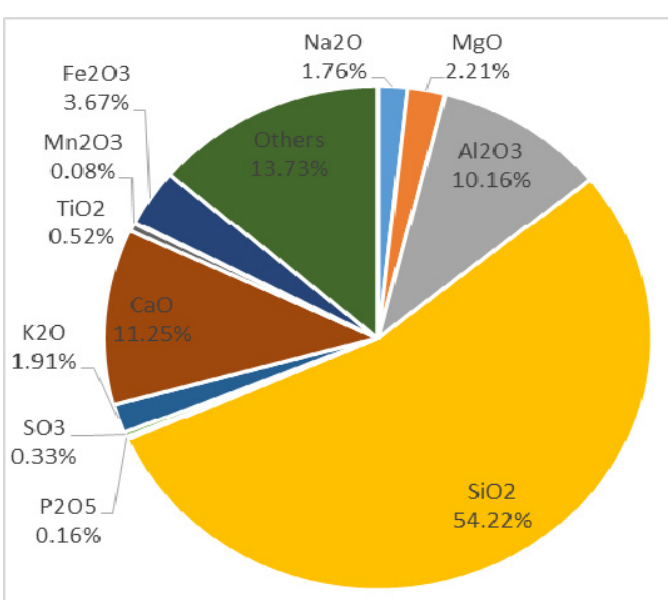

Figure 1. Average values of the content of compounds (\%) in aerosol dust samples.

Attention is drawn to the increased content of $\mathrm{SiO}_{2}, \mathrm{CaO}, \mathrm{Al}_{2} \mathrm{O}_{3}$ and $\mathrm{Fe}_{2} \mathrm{O}_{3}$. These are compounds, usually characteristic of the soil.

Figure 2 shows the dynamics of changes in the content of these compounds over the period 2007-2015 (no data for 2012).

High values of $\mathrm{Fe}_{2} \mathrm{O}_{3}, \mathrm{SO}_{3}$ and $\mathrm{TiO}_{2}$ are observed in 2007 and 2011, low value $\mathrm{SiO}_{2}, \mathrm{CaO}$ and $\mathrm{Na}_{2} \mathrm{O}$ are observed in 2007 and 2011, and the remaining compounds vary within the average for the series (Fig. 2).

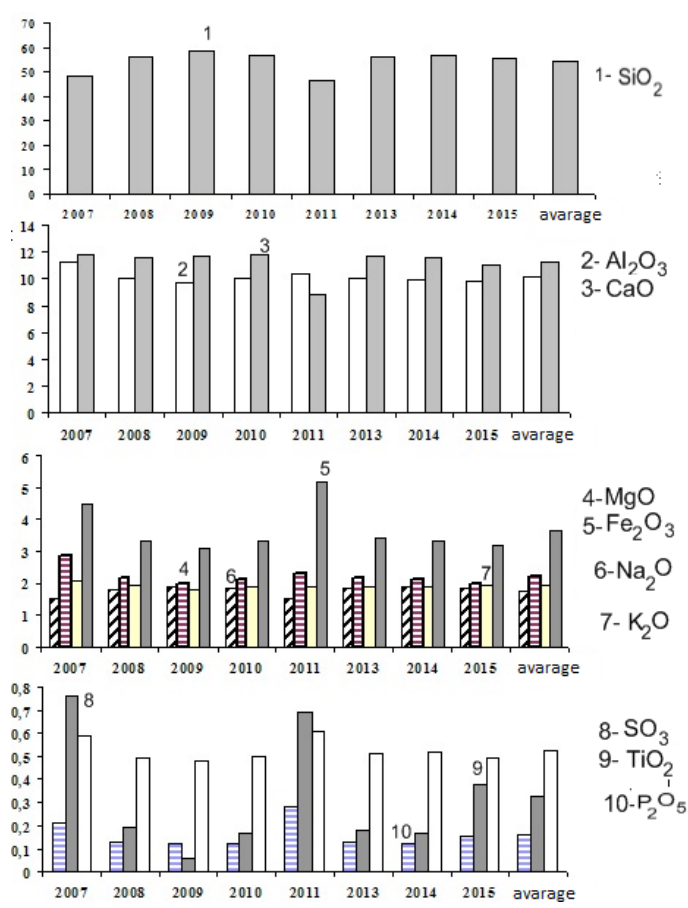

Figure 2. Dynamics of changes in the content of compounds in aerosol dust samples for the period 20072015.

Correlation coefficients which were calculated between the compounds indicated that the highest correlation is found between $\mathrm{SiO}_{2}$ and $\mathrm{Na}_{2} \mathrm{O}(\mathrm{r}=0.98)$; between $\mathrm{Fe}_{2} \mathrm{O}_{3}$ and $\mathrm{SO}_{3}(\mathrm{r}=0.89)$; between $\mathrm{Fe}_{2} \mathrm{O}_{3}$ and $\mathrm{Al}_{2} \mathrm{O}_{3}$; between $\mathrm{K}_{2} \mathrm{O}$ and $\mathrm{MgO}(\mathrm{r}=0.87)$; between $\mathrm{Al}_{2} \mathrm{O}_{3}$ and $\mathrm{MgO}(\mathrm{r}=0.77)$; between $\mathrm{CaO}$ and $\mathrm{Na}_{2} \mathrm{O}$ $(\mathrm{r}=0.56)$. For the other compounds, significant correlation was not detected. Table 2 shows the content of the statistical characteristics of the compounds.

Table 2. The average, minimum and maximum percentage content $\mathrm{C}$ of compounds in aerosol samples dust,

$\sigma$ - standard deviation, $\mathrm{S}_{\mathrm{n}}$ - standard error and $\mathrm{V}$ - data variation.

\begin{tabular}{|l|l|l|l|l|l|l|}
\hline $\begin{array}{l}\text { Compou } \\
n d, \%\end{array}$ & $<\mathrm{C}>$ & $C_{\max }$ & $C_{\text {min }}$ & $\sigma$ & $\mathrm{Sn}_{n}$ & $\mathrm{~V}$ \\
\hline $\mathrm{Na}_{2} \mathrm{O}$ & $\mathbf{1 . 7 6}$ & $\mathbf{1 . 8 7}$ & $\mathbf{1 . 4 9}$ & 0.14 & 0.05 & 0.08 \\
\hline $\mathrm{MgO}$ & $\mathbf{2 . 2 1}$ & $\mathbf{2 . 8 6}$ & $\mathbf{1 . 9 7}$ & 0.25 & 0.08 & 0.11 \\
\hline $\mathrm{Al}_{2} \mathrm{O}_{3}$ & $\mathbf{1 0 . 1 6}$ & $\mathbf{1 1 . 2 1}$ & $\mathbf{9 . 7 9}$ & 0.41 & 0.14 & 0.04 \\
\hline $\mathrm{SiO}_{2}$ & $\mathbf{5 4 . 2 3}$ & $\mathbf{5 8 . 5 4}$ & $\mathbf{4 6 . 4 1}$ & 3.93 & 1.31 & 0.07 \\
\hline $\mathrm{P}_{2} \mathrm{O}_{5}$ & 0.16 & 0.28 & 0.12 & 0.05 & 0.02 & 0.32 \\
\hline $\mathrm{SO}_{3}$ & 0.33 & 0.76 & 0.06 & 0.23 & 0.08 & 0.71 \\
\hline $\mathrm{K}_{2} \mathrm{O}$ & $\mathbf{1 . 9 1}$ & $\mathbf{2 . 0 8}$ & $\mathbf{1 . 7 9}$ & 0.07 & 0.02 & 0.04 \\
\hline $\mathrm{CaO}$ & $\mathbf{1 1 . 2 5}$ & $\mathbf{1 1 . 7 7}$ & $\mathbf{8 . 8 7}$ & 0.88 & 0.29 & 0.08 \\
\hline $\mathrm{TiO}_{2}$ & 0.52 & 0.61 & 0.48 & 0.04 & 0.01 & 0.08 \\
\hline $\mathrm{Mn}_{2} \mathrm{O}_{3}$ & 0.08 & 0.1 & 0.07 & 0.01 & 0 & 0.09 \\
\hline $\mathrm{Fe}_{2} \mathrm{O}_{3}$ & $\mathbf{3 . 6 7}$ & $\mathbf{5 . 1 5}$ & $\mathbf{3 . 0 9}$ & 0.66 & 0.22 & 0.18 \\
\hline $\mathrm{Others}_{2}$ & 13.73 & 21.83 & 10.52 & 3.29 & 1.1 & 0.24 \\
\hline
\end{tabular}

Acknowledgment: The studies were carried out with the financial support of the International Science and Technology Center (ISTC) Projects T1688 and T-2076. The studies were carried out also with the financial support of the Academy of Sciences of the Republic of Tajikistan. 


\section{References}

[1] N.M. Mahowald, R.G. Bryant, J. del Corral, L. Steinberger, Geophys. Res. Lett. 30(2), 1074 (2003)

[2] S. Engelstaedter, I. Tegen, R. Washington, Earth Sci. Rev. 79(1), 73-100 (2006)

[3] I. Koren, Y.J. Kaufman, R. Washington, M.C. Todd, Y. Rudich, J.V. Martins, and D. Rosenfeld 2006, Environ. Res. Lett. 1(1), 014005 (2006)

[4] M.C. Baddock, J.E. Bullard, R.G. Bryant, Remote Sens. Environ. 113, 1511-1528 (2009)

[5] L. Orlovsky, N. Orlovsky, A. Durdyev, J. Arid Environ. 60(1), 83-97 (2005)

[6] S.W. Breckle, W. Wucherer, A. Liliya L.A. Dimeyeva, N.P. Ogar (eds.), Aralkum - A Man-Made Desert: The Desiccated Floor of the Aral Sea (Central Asia), Springer Berlin Heidelberg (2012)

[7] M.C. Reheis, J. Geophys. Res. 102(D22), 2599926008 (1997)

[8] M.C. Reheis, J.R. Budahn, P.J. Lamothe, R.L. Reynolds, J. Geophys. Res. 114, F01028 (2009)

[9] J.W. Whitney, Geology, Water, and Wind in the Lower Helmand Basin, Southern Afghanistan, U.S. Geological Survey, Reston, Virginia, https://pubs.usgs.gov/sir/2006/5182/pdf/SIR065182_508.pdf, last access 2 April 2019 (2006)

[10]A. Rashki, D. Kaskaoutis, C.J.deW. Rautenbach, P. Eriksson. Atmospheric Aerosols--Regional Characteristics - Chemistry and Physics, Chapter 6, Hayder Abdul-Razzak (ed.), IntechOpen (2012) 